\title{
THE GROWTH RATE OF THE LONG ROUGH DAB HIPPOGLOSSOIDES PLATESSOIDES (FABR.)
}

\author{
By T. B. Bagenal \\ The Marine Station, Millport \\ (Plate I and Text-figs. I-6)
}

The Long Rough Dab, Hippoglossoides platessoides (Fabr.), is a common fish in the Clyde Sea Area, being indeed the most abundant flatfish. However, despite its abundance and its wide geographic range (it is found from the British coasts as far north as Spitzbergen and the Murman coast, Iceland, Greenland and south to Cape Cod in America), very little work has been done on its general biology. This is no doubt owing to its having little or no economic value. Concerning its growth rate, which is the subject of this paper, the European subspecies limandoides (Bloch) (see Norman, 1934) has been investigated to some extent in the Barents Sea (Essipow \& Slastnikow, I932; and Milinsky, 1944), and has been mentioned in more general papers by Saemundsson (1925) and Krüger (1942) for Icelandic and Baltic populations respectively. The American population which constitutes a separate subspecies platessoides, has been discussed by Huntsman (I9I8), though he does not give much numerical data on the growth rate.

In the work described below the ages of $156 \mathrm{I} \mathrm{H}$. platessoides limandoides caught in the Clyde area have been determined and their growth rate calculated.

\section{GEAR}

The gear used in obtaining the samples on which this work is based was a small-mesh cotton v.D. trawl of the following dimensions: headline, $49 \mathrm{ft}$.; foot rope, $78 \mathrm{ft}$.; bridles, I5 fathoms; lower wings and belly mesh size, $2 \frac{1}{2}$ in. bar; all other meshes, I in. bar. This gear took an adequate sample of the population, except that the mesh-size selection gave a noticeably biased sample of the younger age-groups. This point will be discussed in a later section (p. 305). In order to illustrate the adequacy of the gear in obtaining representative samples two tests were carried out on a pair of hauls taken over the same ground on 8 July I954. In the first test (see Table I) the mean lengths of the age-groups present were compared and no significant differences were found. In the second test the numbers of fish of each age-group were compared, and again no significant differences were found. 


\section{The Material and Methods}

The samples were obtained monthly, and for the most part the fish were caught in an area at about $40 \mathrm{~m}$. depth off Mountstuart House on the east side of the Isle of Bute. Before this area was finally chosen some of the earlier hauls were taken on various grounds round the Isle of Cumbrae, and prior to the spawning time hauls were also taken in the deeper water between Bute and Cumbrae. Owing to the depth segregation of spawning and immature fish, and so also of the relative proportions of different sizes and ages, these latter hauls led to the samples being more representative of the population as a whole.

Table I. Comparison of two Replicate Catches of Long Rough Dabs

$\begin{array}{cccccc}\text { Age-group } & \overbrace{\text { Number }}^{\begin{array}{c}\text { Mean length } \\ (\mathrm{cm})\end{array}} & \overbrace{\text { Number }}^{\text {Maul I }} & \begin{array}{c}\text { Mean length } \\ (\mathrm{cm})\end{array} \\ 2 & \text { I5 } & \text { I3.2 } & \text { I2 } & \text { I3.4 } \\ 3 & 33 & \text { I8.8 } & 26 & \text { I8.3 } \\ 4 & 22 & 23 \cdot I & 24 & 22 \cdot 7 \\ 5 & 9 & 23 \cdot I & 5 & 24 \cdot 0\end{array}$

The dates on which the samples were obtained are given in Table II.

The examination of the fish after capture was carried out in the laboratory, and for the purposes of this investigation, the sex and length of each fish was noted and the otoliths were extracted and stored in separate packets. The lengths were measured from the tip of the lower jaw to the end of the longest caudal fin ray to the nearest $0.5 \mathrm{~cm}$. These measurements however were later grouped into centimetre groups, and the resulting groups of from $x-0.25 \mathrm{~cm}$ to $x+0.75 \mathrm{~cm}$ were all classed as $x \mathrm{~cm}$ rather than $x .25 \mathrm{~cm}$ for ease in computation.

\section{Age Determination}

The ages of the fish were determined from the otoliths (Pl. I). These were examined as soon as possible after extraction, in a strongly illuminated black dish. They were found to be very clear and easy to read. The number of translucent rings that alternate with opaque bands was noted and taken to represent the age of the fish in years.

In order to test the accuracy of the otolith readings some scales were examined from a few fish, but they proved to be very obscure and difficult to read and the attempt was abandoned. However, the edges of the otoliths were examined and the percentage that were translucent was calculated. The data are given in Table III and it can be seen that the assumption that the rings are annual structures is confirmed.

From the age analysis each fish was allocated to a population $a-f$ dependent on when it was supposed to have been spawned. This obviates the difficulty 
during the winter and spring when fish that were spawned in a given year may have a different number of translucent rings dependent on the condition of the outer edge.

Table II. Details of Long Rough Dab Catches

\begin{tabular}{|c|c|c|c|c|c|c|c|c|c|c|c|c|c|c|c|}
\hline \multirow{2}{*}{ Population ... } & \multicolumn{2}{|c|}{$a$} & \multicolumn{2}{|c|}{$b$} & \multicolumn{2}{|c|}{ c } & \multicolumn{2}{|c|}{$d$} & \multicolumn{2}{|c|}{$e$} & & \multicolumn{2}{|c|}{ Totals } & \multirow{2}{*}{$\begin{array}{c}\text { Grand } \\
\text { totals }\end{array}$} \\
\hline & $\hat{0}$ & q & o & 우 & o & 우 & o & 우 & t & 우 & $\hat{0}$ & $q$ & o & 우 & \\
\hline \multicolumn{16}{|l|}{ I953 } \\
\hline 23 Oct. & - & - & - & 4 & I & I3 & - & 22 & I & $2 \mathrm{I}$ & 5 & 5 & 7 & 65 & 72 \\
\hline I9 Nov. & - & - & - & - & 3 & 9 & 2 & I5 & 3 & I8 & 2 & . & I0 & $5 \mathrm{I}$ & $6 \mathrm{I}$ \\
\hline I5 Dec. & - & - & - & 2 & I & 5 & I & I7 & I & I8 & 2 & 6 & 5 & 48 & 53 \\
\hline \multicolumn{16}{|l|}{ I954 } \\
\hline $\begin{array}{l}21 \text { Jan. } \\
26 \text { Jan. }\end{array}$ & - & - & - & 6 & I & $2 \mathrm{I}$ & I & 28 & 2 & 22 & I & 3 & 5 & 80 & 85 \\
\hline I5 Feb. & - & - & - & 3 & - & I2 & - & $\begin{array}{l}30 \\
78\end{array}$ & 一 & 4 & - & - & - & 49 & 49 \\
\hline 2 Mar. & 二 & - & 二 & 7 & 2 & 26 & 2 & 78 & 4 & 149 & I & 8 & 9 & 268 & 277 \\
\hline $30 \mathrm{Mar}$. & 二 & 4 & - & $\begin{array}{r}3 \\
8\end{array}$ & 二 & 18 & 二 & 36 & - & 44 & - & - & - & I05 & 105 \\
\hline 8 Apr. & - & I & - & I8 & - & 27 & - & 52 & - & 48 & - & I & - & I47 & I47 \\
\hline 3 May & - & - & - & 8 & I & I5 & 2 & 30 & 2 & 59 & - & 5 & 5 & [I7 & 122 \\
\hline 2 Ju & - & I & - & 2 & 4 & I6 & $\mathrm{I} 2$ & 54 & IO & 98 & 3 & 6 & 29 & I 77 & 206 \\
\hline 8 July & - & - & - & I & I & I4 & 7 & 46 & 5 & 59 & 3 & I5 & I6 & 135 & I5I \\
\hline 9 Aug. & - & - & - & I & 4 & IO & I3 & 36 & I5 & 46 & 5 & 23 & 37 & II6 & 153 \\
\hline 7 Sept. & - & - & - & 2 & I & 5 & 8 & I6 & - & 35 & 3 & IO & 12 & 68 & 80 \\
\hline Total & - & 6 & - & 57 & I9 & I9I & 48 & 460 & 43 & $62 \mathrm{I}$ & 25 & $9 \mathrm{r}$ & I35 & I 426 & I56I \\
\hline
\end{tabular}

Table III. Percentage of Otoliths with Translucent Edges

$\begin{array}{lllr}\text { Oct. } & 36 \cdot 5 & \text { Apr. } & 50 \cdot 2 \\ \text { Nov. } & 46 \cdot 1 & \text { May } & \text { I0.7 } \\ \text { Dec. } & 75 \cdot 2 & \text { June } & 18 \cdot 0 \\ \text { Jan. } & 74 \cdot 2 & \text { July } & 7 \cdot 4 \\ \text { Feb. } & 83 \cdot 7 & \text { Aug. } & 10 \cdot 6 \\ \text { Mar. } & 74 \cdot 3 & \text { Sept. } & 15 \cdot 2\end{array}$

\section{Growth Rate}

In the analysis of the growth rate the two sexes were treated separately. For each population sample in each month the mean length was calculated, and its $95 \%$ fiducial limits obtained for all samples where sufficient numbers were caught. The data for the females are given in Table IV and for the males in Table V, though for the latter the numbers are unfortunately too small to make calculation of fiducial limits worth while. It can immediately be seen that the males are not only of a smaller size than females of a corresponding age, but also that they have a shorter life span (see also Fig. 3).

The data in Table IV are shown in Fig. I. From this it can be seen that the most rapid growth takes place in the younger fish and falls off in later years. The seasonal differences in growth rate can also be seen, the faster growth taking place between April and November. It will be noticed that this period of faster growth is at a time when the edge of the majority of otoliths is opaque 
Table IV. Mean Lengths (and their Fiducial Limits) of Female Long Rough Dabs from Populations $a$ to $f$

\begin{tabular}{|c|c|c|c|c|c|c|c|c|c|c|c|c|c|c|c|c|}
\hline Population $\ldots$ & $a$ & & $b$ & & & $c$ & & & $d$ & & & $e$ & & & $f$ & \\
\hline & Mean & $\begin{array}{l}\text { Lower } \\
\text { limit }\end{array}$ & Mean & $\begin{array}{l}\text { Upper } \\
\text { limit }\end{array}$ & $\begin{array}{l}\text { Lower } \\
\text { limit }\end{array}$ & Mean & $\begin{array}{l}\text { Upper } \\
\text { limit }\end{array}$ & $\begin{array}{l}\text { Lower } \\
\text { limit }\end{array}$ & Mean & $\begin{array}{l}\text { Upper } \\
\text { limit }\end{array}$ & $\begin{array}{l}\text { Lower } \\
\text { limit }\end{array}$ & Mean & $\begin{array}{l}\text { Upper } \\
\text { limit }\end{array}$ & $\begin{array}{l}\text { Lower } \\
\text { limit }\end{array}$ & Mean & $\begin{array}{l}\text { Upper } \\
\text { limit }\end{array}$ \\
\hline Oct. & - & - & $25 \cdot 5$ & - & $22 \cdot 0$ & 23.4 & $24 \cdot 7$ & $2 I \cdot 2$ & $21 \cdot 9$ & $22 \cdot 7$ & $16 \cdot 3$ & $17 \cdot 0$ & $17 \cdot 8$ & - & $10 \cdot 0$ & - \\
\hline Nov. & - & - & - & - & $20 \cdot 8$ & $22 \cdot 7$ & $24 \cdot 4$ & $20 \cdot 4$ & $2 \mathrm{I} \cdot 6$ & $22 \cdot 8$ & $16 \cdot 6$ & $17 \cdot 6$ & 18.5 & II $\cdot I$ & I $2 \cdot 3$ & 13.6 \\
\hline Dec. & - & - & 17.5 & - & I7.7 & $2 I \cdot 0$ & $24 \cdot 3$ & I9.8 & $2 \mathrm{I} \cdot \mathrm{I}$ & $22 \cdot 3$ & I7. I & 18.0 & 18.9 & II $\cdot O$ & I $2 \cdot 7$ & I $4 \cdot 3$ \\
\hline Jan. & - & $24 \cdot 2$ & $26 \cdot 3$ & 28.5 & $23 \cdot I$ & $24 \cdot I$ & $25 \cdot 2$ & $2 I \cdot I$ & $2 \mathrm{I} \cdot 7$ & $22 \cdot 3$ & I6.9 & $17 \cdot 8$ & I8.7 & - & II $\cdot 7$ & - \\
\hline Feb. & - & - & $27 \cdot 7$ & - & $23 \cdot I$ & $24 \cdot 5$ & 25.9 & $22 \cdot 3$ & $22 \cdot 8$ & $23 \cdot 3$ & $17 \cdot 2$ & 18.5 & 19.9 & - & - & - \\
\hline Mar. & - & $24 \cdot 7$ & $26 \cdot 4$ & $28 \cdot 2$ & $2 \mathrm{I} \cdot 7$ & $22 \cdot 7$ & $23 \cdot 6$ & $2 \mathrm{I} \cdot 3$ & $2 I \cdot 5$ & $2 \mathrm{I} \cdot 7$ & I7. I & $17 \cdot 4$ & $17 \cdot 7$ & - & $9 \cdot 8$ & - \\
\hline Mar. & 26 & - & $25 \cdot 3$ & - & $2 x \cdot 5$ & $22 \cdot 6$ & $23 \cdot 8$ & $2 I \cdot 3$ & $22 \cdot 0$ & $22 \cdot 6$ & $17 \cdot 9$ & 18.5 & I9. I & - & - & - \\
\hline Apr. & 22 & 23.4 & $24 \cdot 4$ & 25.5 & $22 \cdot I$ & $23 \cdot I$ & 23.9 & $21 \cdot 7$ & $22 \cdot I$ & $22 \cdot 6$ & 18.0 & $18 \cdot 6$ & I9. I & - & I I & - \\
\hline May & - & $23 \cdot I$ & $25 \cdot 3$ & $27 \cdot 4$ & $22 \cdot I$ & $23 \cdot 7$ & $25 \cdot 3$ & $2 I \cdot 3$ & $22 \cdot 2$ & $23 \cdot I$ & $17 \cdot 6$ & $18 \cdot 2$ & 18.7 & - & $10 \cdot 8$ & - \\
\hline June & 26 & - & 25.0 & - & 23.2 & $24 \cdot 5$ & 25.8 & $2 \mathrm{I} \cdot 8$ & 22.5 & $23 \cdot I$ & I7. 8 & $18 \cdot 2$ & I8.6 & 10.7 & $\mathrm{I} 2 \cdot \mathrm{O}$ & 13.3 \\
\hline July & - & - & $2 \mathrm{I}$ & - & 22.5 & $23 \cdot 4$ & $24 \cdot 4$ & $22 \cdot 3$ & 22.9 & 23.5 & I $8 \cdot 0$ & 18.5 & 19.0 & $12 \cdot 4$ & 13.2 & I 4.0 \\
\hline Aug. & - & - & 23 & - & $22 \cdot I$ & $24 \cdot I$ & $26 \cdot I$ & $21 \cdot 5$ & $22 \cdot I$ & $22 \cdot 8$ & 19.4 & 19.9 & $20 \% 4$ & 13.0 & 13.6 & $14 \cdot 2$ \\
\hline Sept. & - & - & 24.5 & - & $2 I \cdot 7$ & $23 \cdot 8$ & 25.9 & $2 I \cdot 5$ & $22 \cdot 8$ & $24 \cdot 0$ & 19.5 & $20 \cdot 3$ & $2 I \cdot O$ & 13.4 & 14.6 & 15.8 \\
\hline Mean for the year & $25 \cdot 3$ & 24.7 & $25 \cdot 3$ & $26 \cdot 0$ & $23 \cdot I$ & $23 \cdot 4$ & $23 \cdot 7$ & $21 \cdot 9$ & $22 \cdot I$ & $22 \cdot 3$ & $\mathrm{I} 8 \cdot \mathrm{I}$ & 18.3 & I 8.4 & $\mathrm{I} 2 \cdot 2$ & $12 \cdot 6$ & 13.0 \\
\hline
\end{tabular}




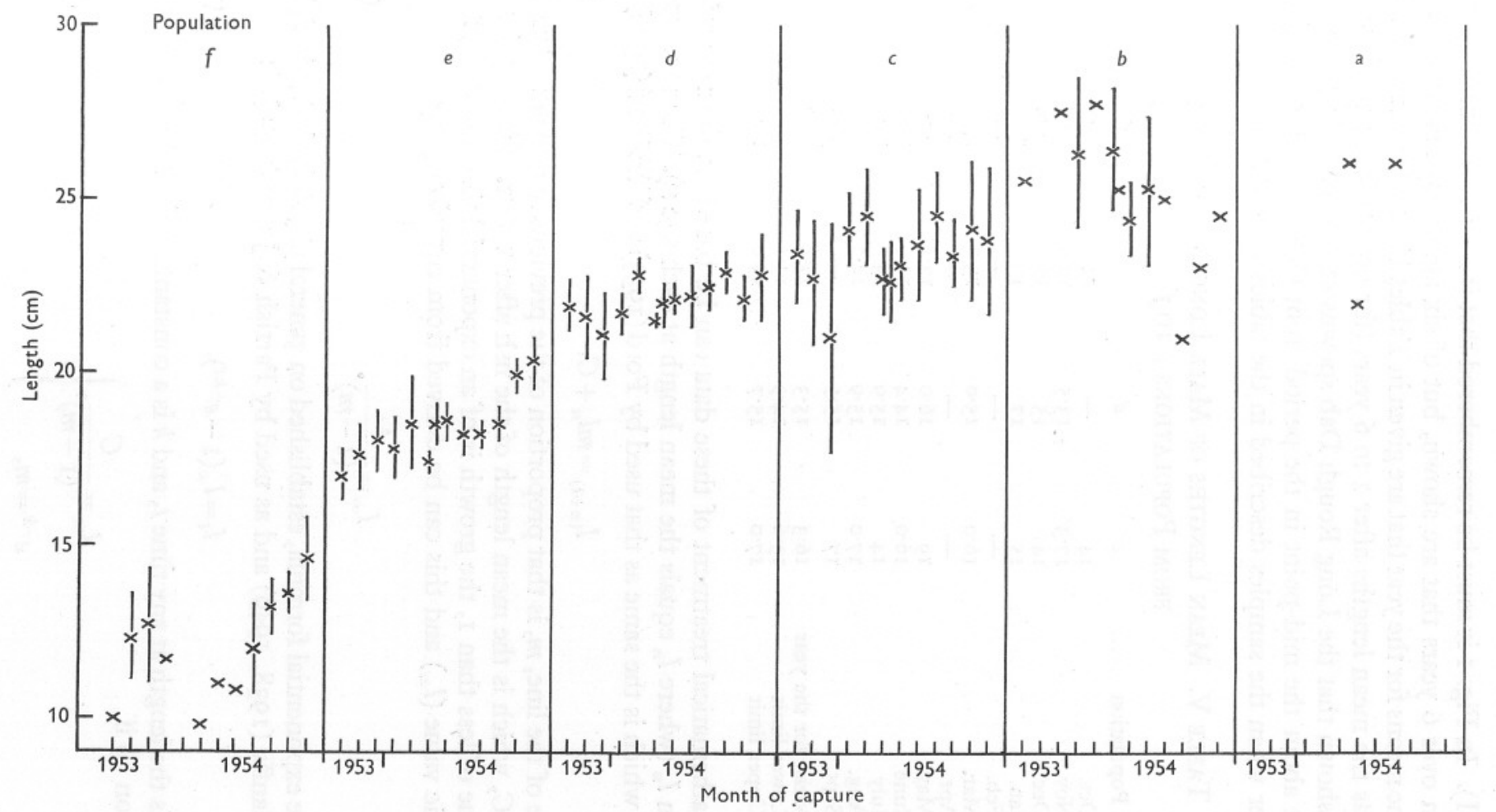

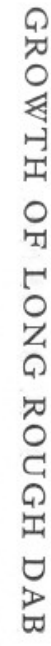

Fig. I. The means $(x)$ and their $95 \%$ fiducial limits (vertical lines) of female Long Rough Dabs of six populations, $a-f$, from samples taken from October 1953 to September 1954 
(Table III). In Fig. I it must be remembered that it is not samples from one generation over 6 years that are shown, but of six age-groups sampled over I year. The means for the year that are given in Tables IV and V can reasonably be taken as the mean lengths after I to 6 years (for populations $f$ to $a$ ), since it can be shown that the Long Rough Dab spawns at the beginning of April, that is, at about the mid-point in the period from October to the following September when the samples described in the tables were taken.

\begin{tabular}{|c|c|c|c|c|}
\hline Population & c & $d$ & $e$ & $f$ \\
\hline Oct. & I4 & - & II & $8 \cdot 8$ \\
\hline Nov. & $17 \cdot 3$ & .13 .5 & $12 \cdot 0$ & 10.5 \\
\hline Dec. & $I_{4}$ & 15 & I4 & 10.5 \\
\hline Jan. & 15 & 17 & $13 \cdot 0$ & Io \\
\hline Mar. & $\overline{16.0}$ & 15.0 & $13 \cdot 0$ & I3 \\
\hline Apr. & - & $\frac{1}{60}$ & - & 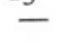 \\
\hline $\begin{array}{l}\text { May } \\
\text { June }\end{array}$ & $\begin{array}{l}19 \\
16 \cdot 0\end{array}$ & $16 \cdot 0$ & 13.5 & \\
\hline $\begin{array}{l}\text { June } \\
\text { July }\end{array}$ & 14 & $\begin{array}{l}14.4 \\
15.9\end{array}-9$ & $\begin{array}{l}13.0 \\
13.8\end{array}$ & $\begin{array}{lll}\mathrm{II} \cdot 0 \\
\mathrm{TI} \cdot \mathrm{s}\end{array}$ \\
\hline $\begin{array}{l}\text { July } \\
\text { Aug. }\end{array}$ & $\begin{array}{l}14 \\
17 \cdot 0\end{array}$ & $\begin{array}{l}139 \\
15.9\end{array}$ & $\begin{array}{l}150 \\
14.3\end{array}$ & $\begin{array}{l}11.3 \\
10.8\end{array}$ \\
\hline Sept. & I7 & 15.5 & - & 10.7 \\
\hline Mean for the year & $16 \cdot 3$ & I5.3 & I3.5 & \\
\hline & $15 \cdot 6$ & I 4.9 & 13.0 & \\
\hline $\mathrm{r}$ limit & $17 \cdot 0$ & $15 \cdot 7$ & $14 \cdot 0$ & \\
\hline
\end{tabular}

The mathematical treatment of these data can be based on the regression of $l_{(n+1)}$ on $l_{n}$ (where $l_{n}$ equals the mean length at each age $n$ ). The regression equation, which is the same as that used by Ford (1933) and Walford (1946), is

$$
l_{(n+1)}=m l_{n}+C .
$$

The slope of the line, $m$, is that proportion of the previous length added to the constant $C$, which is the mean length of the fish after I year. Since $m$ always has a value of less than $I$, the growth is of an exponential form, tending to an asymptotic value $\left(l_{\infty}\right)$ and this can be derived from equation (i) as

$$
l_{\infty}=\frac{C}{(\mathrm{I}-m)} \text {. }
$$

A suitable exponential formula, established on general physiological principles by Bertalanffy (1938, 1949) and as used by Parrish \& Jones (1953), is

$$
l_{t}=l_{\infty}\left(\mathrm{I}-e^{-k t}\right),
$$

where $l_{t}$ is the length at any time $t$, and $k$ is a constant. This will be equivalent to equation (i) if

$$
\left.\begin{array}{rl}
l_{\infty} & =\frac{C}{(\mathrm{I}-m)}, \\
e^{-k} & =m,
\end{array}\right\}
$$


and the constant $(C)$ is the length at I year old. This last condition is necessary because the exponential equation passes through the origin, whereas the regression allows a value for $l_{0}$ (which may perhaps represent the length of the fish when the otolith formation commences). However, if a comparison of the regression equation and the data suggests that a value for $l_{0}$ should be calculated, this can be obtained from equation (i), and if one wishes to fit the exponential equation (iii) so that $l_{0}$ has this value, the origin of $t$ must be changed by an amount $x$, such that the lengths are calculated for values of $t=n+x$. Equation (iii) now becomes:

and writing $n=0$ we get

$$
l_{n}=l_{\infty}\left(\mathrm{I}-m^{n+x}\right),
$$

$$
x=\frac{\log \left(l_{\infty}-l_{0}\right)-\log l_{\infty}}{\log m} .
$$

In the analysis of the data by these methods, the regression equations (i) were calculated from the mean lengths given in Tables IV and V, care being taken to weight the points in proportion to the number of fish contributing to each mean. The equations found were

$$
\left.\begin{array}{l}
\text { for the females: } l_{n+1}=0.574 l_{n}+\mathrm{II} \cdot 262, \\
\text { for the males: } l_{n+1}=0.585 l_{n}+7 \cdot 368 ;
\end{array}\right\}
$$

and the $l_{\infty}$ values therefore were given by

$$
\left.\begin{array}{l}
\text { for the females: } l_{\infty}=\frac{\mathrm{II} \cdot 262}{(\mathrm{I}-0.574)}=26.437 \mathrm{~cm}, \\
\text { for the males: } l_{\infty}=\frac{7.368}{(\mathrm{I}-0.585)}=\mathrm{I} 7.754 \mathrm{~cm} .
\end{array}\right\}
$$

These values in the exponential equation (3) give

$$
\left.\begin{array}{l}
\text { for the females: } l_{t}=26.437\left(\mathrm{I}-0.574^{t}\right), \\
\text { for the males: } l_{t}=\mathrm{I} 7.754\left(\mathrm{I}-0.585^{t}\right) .
\end{array}\right\}
$$

Successive values of $l_{l}$ are given in Table VI and Fig. 2. It will be noticed that the constant $(C)$ in equation (vii) is not equal to the observed $l_{1}$ so that a value for $l_{0}$ can be obtained. If this is calculated from $l_{1}$

$$
\left.\begin{array}{l}
\text { for the females: } l_{0}=2.33 \mathrm{~cm}, \\
\text { for the males: } l_{0}=5.35 \mathrm{~cm} .
\end{array}\right\}
$$

The accuracy of these values is dependent on the accuracy of $l_{1}$, and a better estimate can be obtained from the data as a whole by finding 
a weighted $l_{0}$ from all the age groups (using equation (vii)). This method gives

$$
\left.\begin{array}{l}
\text { for the females: } l_{0}=2 \cdot 130 \mathrm{~cm}, \\
\text { for the males: } l_{0}=5 \cdot 335 \mathrm{~cm} .
\end{array}\right\}
$$

Using these values in equation (vi) we get

$$
\left.\begin{array}{l}
\text { for the females: } x=0.15 \text { I years, } \\
\text { for the males: } x=0.667 \text { years; }
\end{array}\right\}
$$

\begin{tabular}{|c|c|c|c|c|}
\hline \multirow[b]{2}{*}{$t$} & \multicolumn{2}{|c|}{ Females } & \multicolumn{2}{|c|}{ Males } \\
\hline & Observed & Calculated & Observed & Calculated \\
\hline & $\begin{array}{l}\text { I2.6 } \\
\text { I } 8.3\end{array}$ & $\begin{array}{l}\mathrm{II} \cdot 3 \\
\mathrm{I} 7 \cdot 7\end{array}$ & $\begin{array}{l}10.5 \\
13.5\end{array}$ & $\begin{array}{r}7 \cdot 4 \\
I 1 \cdot 7\end{array}$ \\
\hline & $22 \cdot \mathrm{I}$ & $2 \mathrm{I} \cdot 4$ & $\begin{array}{l}15.3 \\
15 \cdot 3\end{array}$ & $14 \cdot 2$ \\
\hline & $23 \cdot 4$ & $23 \cdot 6$ & $16 \cdot 3$ & $15 \cdot 7$ \\
\hline & $\begin{array}{l}25 \cdot 3 \\
25 \cdot 3\end{array}$ & $\begin{array}{l}24 \cdot 8 \\
25 \cdot 5\end{array}$ & $=$ & 二 \\
\hline
\end{tabular}

TABle VI. Successive Values of $l_{t}$, FROM Equation (ix)

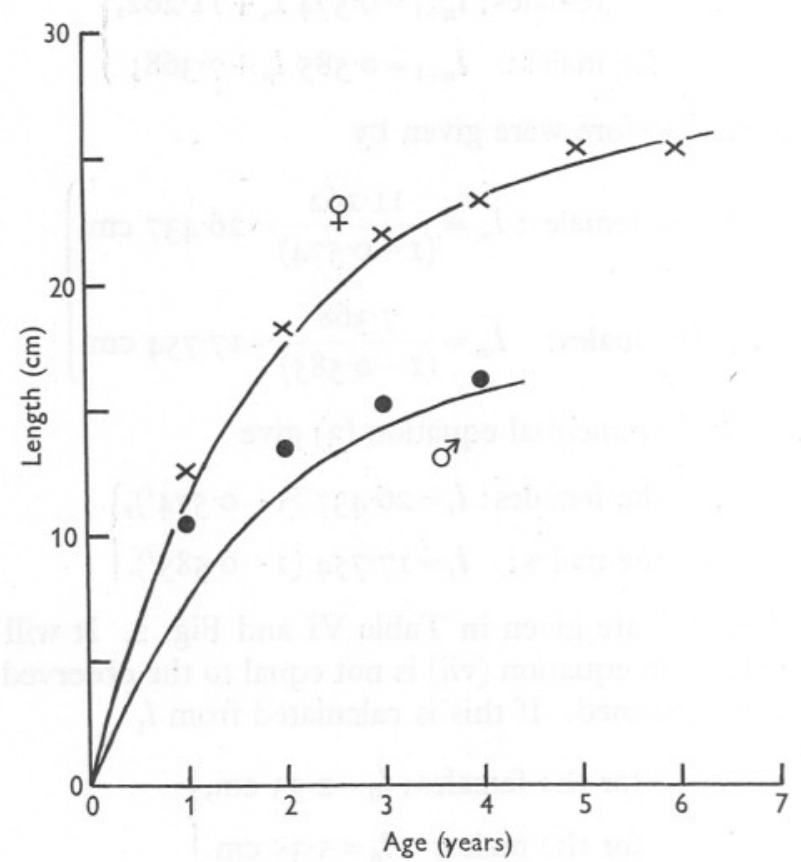

Fig. 2. Observed means and generalized age/length relation of Long Rough Dabs. Females $(x)$, with curve $l_{t}=26.437\left(\mathrm{I}-0.574^{t}\right)$. Males $(\bullet)$, with curve $l_{t}=\mathrm{I} 7.754\left(\mathrm{I}-0.585^{t}\right)$. 
and so equation (v) becomes

$$
\left.\begin{array}{l}
\text { for the females: } l_{n}=26.437\left(\mathrm{I}-0.574^{n+0.151}\right), \\
\text { for the males: } \quad l_{n}=\mathrm{I} 7.754\left(\mathrm{I}-0.585^{n+0.667}\right) .
\end{array}\right\}
$$

Successive values of $l_{n}$ are given in Table VII.

\begin{tabular}{|c|c|c|c|}
\hline \multicolumn{4}{|c|}{ Males } \\
\hline \multicolumn{2}{|c|}{ Observed } & \multicolumn{2}{|c|}{ Calculated } \\
\hline$n=\mathrm{I}$ & 10.5 & $n=\mathrm{r} \cdot 667$ & I0. 49 \\
\hline 2 & 13.5 & 2.667 & 13.51 \\
\hline 3 & 15.3 & 3.667 & $15 \cdot 27$ \\
\hline 4 & $16 \cdot 3$ & 4.667 & 16.30 \\
\hline & 二 & & \\
\hline
\end{tabular}

Table VII. Successive Values of $l_{n}$, FROM Equation (xiii)

\begin{tabular}{|c|c|c|c|}
\hline \multicolumn{4}{|c|}{ Females } \\
\hline \multicolumn{2}{|c|}{ Observed } & \multicolumn{2}{|c|}{ Calculated } \\
\hline$n=\mathrm{I}$ & I $2 \cdot 6$ & $n=\mathrm{I} \cdot \mathrm{I} 5 \mathrm{I}$ & I $2 \cdot 48$ \\
\hline 2 & I 8.3 & $2.15 I$ & I8.44 \\
\hline 3 & $22 \cdot I$ & $3.15 I$ & $2 \mathrm{I} \cdot 84$ \\
\hline 4 & 23.4 & $4.15 I$ & 23.80 \\
\hline 5 & $25 \cdot 3$ & $5.15 \mathrm{I}$ & 24.92 \\
\hline 6 & $25 \cdot 3$ & 6.151 & 25.57 \\
\hline
\end{tabular}

If the lengths given by equation (xiii), which fit the data very well, are the best mathematical approximations to the population, we must examine the meaning of the change $x$ in the time scale; and various hypotheses can be suggested.

First, the values of $l_{0}$ may represent the length of the fish when the otolith formation commenced-or the otolith formation does not start until the fish are $x$ years old-but if this were true it is difficult to see why the values are so different for the males and females. A second interpretation would be to suppose that the value of $x$ may represent the difference between the true anniversary of spawning and that implied in the observed data. This can only mean that the males and females are produced at quite different times, which is absurd.

A third interpretation supposes the sampling contains an inherent bias. It has so far been assumed that the observed mean lengths $(\bar{x})$ are the best estimates of the population means $(\xi)$. If, however, we allow that the sample means may be biased and do not necessarily approximate to the population values, it is suggested that the apparently good fit given in Table VII is a spurious one. The type of factor which would lead up to the kind of bias we are considering might be net mesh-size selection. With such a factor the observed mean lengths would all be too large (cf. Table VI), but if the bias for $l_{n}$ and $l_{(n+1)}$ were even approximately the same, the biased mean lengths of the sample would give similar values of $m$ and $C$ in equation (i) as would the correct population means, since the regression is based on the ratio of $l_{n+1}$ to $l_{n}$ and not on their absolute values. This can be seen from the equation,

$$
m=\frac{l_{n+1}-l_{n}}{l_{n}-l_{n-1}},
$$

since if the mean lengths are similarly biased, the amounts of bias will cancel each other. If this interpretation is correct the calculated mean lengths given 
in Table VI are more likely to represent those of the population than are the observed sample means, and the difference is produced by a factor such as net selection.

\section{TABLE VIII}

\begin{tabular}{|c|c|c|c|c|c|c|c|c|c|c|}
\hline \multirow[b]{2}{*}{ Age } & \multicolumn{6}{|c|}{ Females } & \multicolumn{4}{|c|}{ Males } \\
\hline & I & 2 & 3 & 4 & 5 & 6 & I & 2 & 3 & 4 \\
\hline $\bar{x}$ & 12.6 & I 8.3 & $22 \cdot I$ & 23.4 & $25 \cdot 3$ & $25 \cdot 3$ & 10.5 & I3.5 & $15 \cdot 3$ & $16 \cdot 3$ \\
\hline $\begin{array}{l}\text { Approximate } \\
\text { upper range } \\
\text { limit }\end{array}$ & I9 & 26 & 30 & $3 \mathrm{I}$ & $3 I$ & & 14.5 & 18 & 19 & 20 \\
\hline$\xi$ & II. 3 & $17 \cdot 7$ & $2 \mathrm{I} \cdot 4$ & $23 \cdot 6$ & $24 \cdot 8$ & 25.5 & $7 \cdot 4$ & II $\cdot 7$ & I 4.2 & I5 \\
\hline $3 \sigma$ & $7 \cdot 7$ & $8 \cdot 3$ & $8 \cdot 6$ & $7 \cdot 4$ & $6 \cdot 2$ & - & 7.0 & $6 \cdot 3$ & $4 \cdot 8$ & 0 \\
\hline$\xi+2 \sigma$ & 16.5 & $23 \cdot 3$ & $27 \cdot 2$ & $28 \cdot 6$ & $29 \cdot 0$ & - & 12.0 & 15.9 & I 7.4 & I8. \\
\hline$\xi-2 \sigma$ & $6 \cdot I$ & I $2 \cdot I$ & 15.6 & I 8.6 & $20 \cdot 6$ & - & $2 \cdot 8$ & $7 \cdot 5$ & II.O & I 2. \\
\hline
\end{tabular}
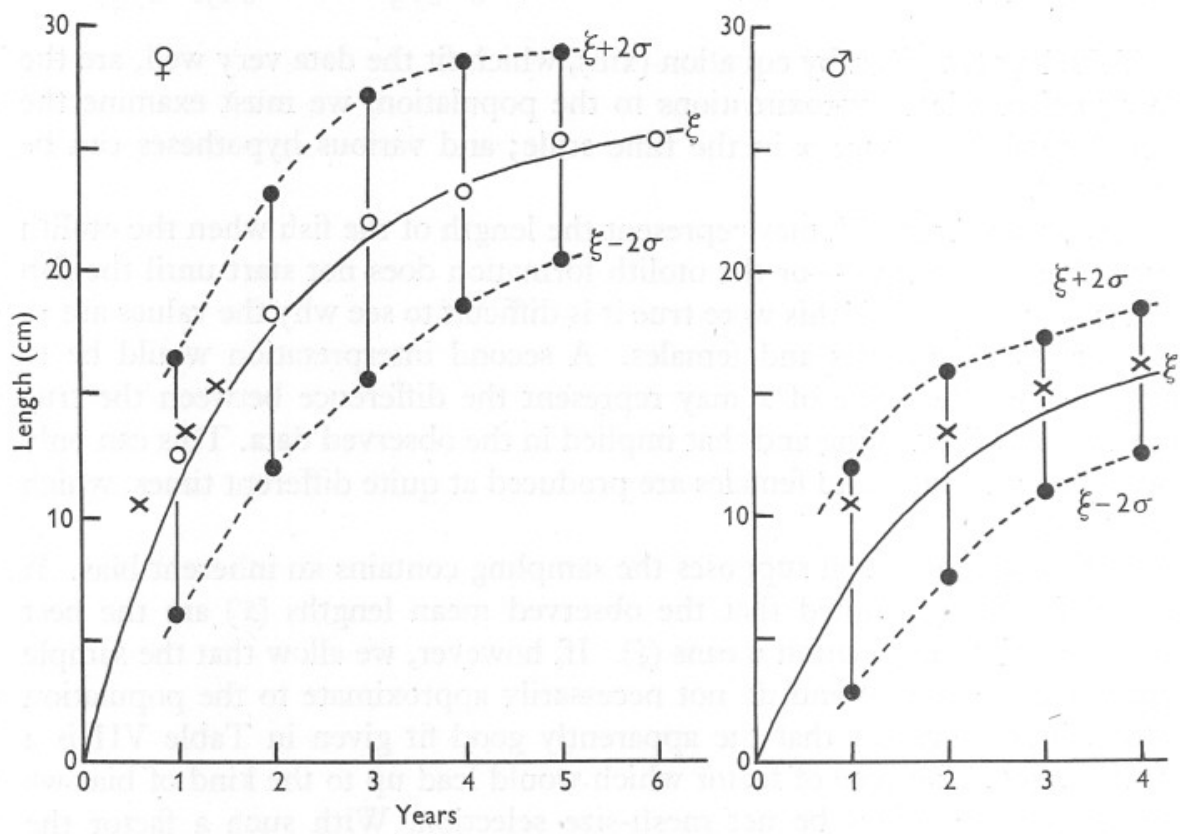

Fig. 3. Diagrams to illustrate the relation of theoretical population means $(\xi)$ and the sample means $(\bar{x}): \bigcirc \cdots \cdots \circ$ for females; $\times \cdots \cdots \times$ for males. (In the left-hand diagram $\times$ represents $\bar{x}$ for males of comparable theoretical size, having been simply transferred from the right-hand diagram.)

Since net-selection bias operates mostly on the smaller fish, we may take the largest observed fish of any age-group to indicate the upper limit of the population range, and if we assume that the length frequency is normally distributed we may take this to represent three standard deviations and thus we may deduce the $2 \sigma$ limits about the mean which should include $95 \%$ of the 
population. These values have been calculated for the males and females and are given in Table VIII and Fig. 3. It will be noticed that the observed lengths are within the $2 \sigma$ limits. It can also be seen from Fig. 3 that the discrepancy between the males and females is very small; the observed mean lengths for the first three age-groups of the males have been transposed to the appropriate position on the graph for the females, and it can be seen that the net selection bias operates very similarly for comparable lengths of both sexes.

The hypothesis of net-selection bias being the reason for the discrepancy between the observed and calculated lengths for each age is not put forward to the exclusion of the other factors given above. It is very unlikely that the observed lengths are those appropriate for whole numbers of years after spawning or the time of otolith formation; nevertheless, it is believed that a hypothesis concerning net selection, or some similar factor, is necessary for a true understanding of the facts. If, because of the time of sampling, it is necessary to change the value of $t$, it must be remembered that the otolith formation will probably commence at the same length in the males and females, so that the lengths at $l_{0}$ should be the same, but that this will be reached sooner by the faster growing sex, which, in Long Rough Dabs of this size, are the females.

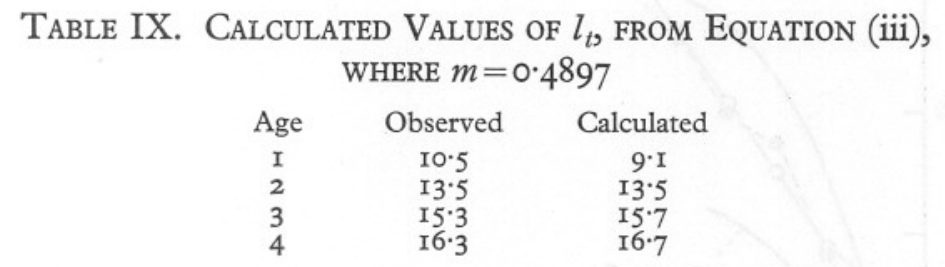

The mathematical treatment of the data in this paper has been based on the regression line of $l_{(n+1)}$ on $l_{n}$, which is the 'best' straight line obtained by the method of least squares, weighted according to the number contributing to the mean length for each age-group. The values of the growth constants obtained in this way are more satisfactory and objective than any that could be obtained by fitting the curve of equation (iii) to the data by trial and error; or by purely graphical methods. The real advantage of the method used in this paper will be appreciated if we consider the growth of the males. By substituting the observed lengths into equation (iv) a weighted mean value for $k$ can be obtained and has been found to be 0.714 , corresponding to $m=0.4897$. The calculated values of $l_{t}$ using this figure in equation (iii) are given in Table IX and give what is apparently a good fit, but there are numerous objections to the method.

It is always easier and more accurate to fit a straight line than a curve; and since the line is based on ratios, if there is bias in the mean lengths which is even approximately similar, better results will be obtained than by using the 
biased observed values separately. Secondly, the slope of the line is not 0.4897 , and it can hardly be fortuitous that the values of $m$ in equation (i) are so similar for both sexes. Furthermore, Bertalanffy (1938) showed that a

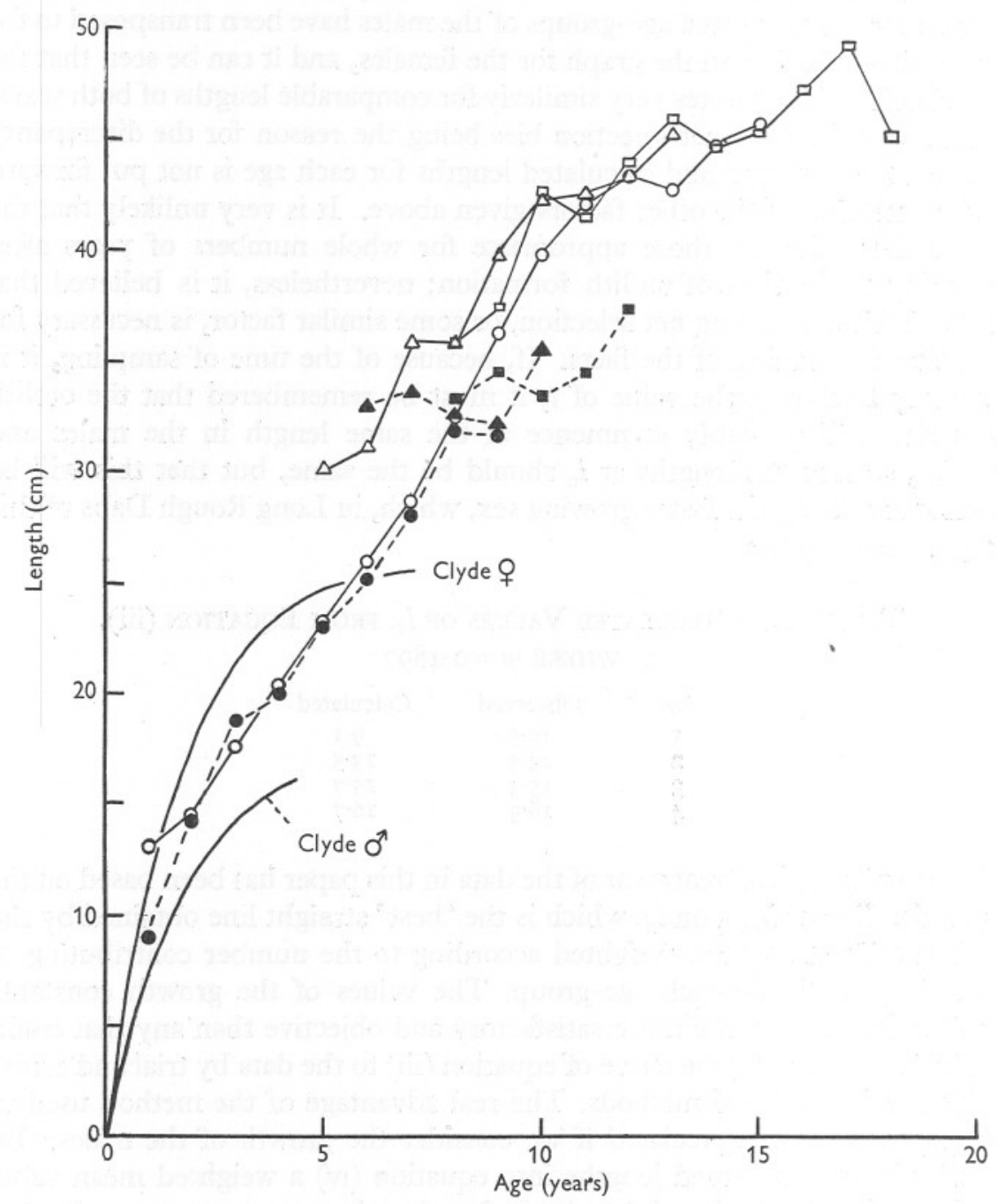

Fig. 4. Comparison of Clyde Long Rough Dab growth rate with that given by Milinsky

(O females, males, from Table II; $\square$ females, males from Table III) and by Essipow \& Slastnikow ( $\Delta$, females, $\boldsymbol{\Delta}$ males) for the Barents Sea.

curve of the form in equation (iii) could be established on physiological principles. If his reasoning is correct the curve should fit the observed data, and any discrepancy will most probably be due to some factor such as biased 
sampling or faulty age determination. The discrepancies found in Table VI can be explained very satisfactorily in this way, but it is hard to see why in Table IX the observed values for both $t=3$ and $t=4$ are too low. It is very important in work of this kind to bear in mind the limitations of the sampling device and to anticipate what differences these may produce on the parameters of the sample as compared with those of the population.

\section{Comparison with Previous Studies}

The most striking point that emerges from a comparison of the age and growth of Clyde-caught Long Rough Dabs and those from elsewhere is the difference in longevity. The ages recorded for Barents Sea specimens given by Essipow \& Slastnikow (1932) range from 5 to I3, and Milinsky (1944) records females of up to I9 years old. Similarly, in Icelandic populations, Saemundsson (1925) found Long Rough Dabs of 17 years old, and Huntsman (I9I8), discussing the American subspecies $H$. $p$. platessoides, states that they can certainly live as long as 24 years, and probably 30 years should be assigned as the upper limit. In the Clyde no specimens have been found that have survived their sixth year.

Similar differences are found in the maximum sizes to which the fish grow. Specimens of $48.0 \mathrm{~cm}$ (Essipow \& Slastnikow, I932) and of over $50 \mathrm{~cm}$ (Milinsky, I944) have been recorded from the Barents Sea, and of $2 \mathrm{ft} .(6 \mathrm{I} \mathrm{cm})$ from Canada (Huntsman, 1918). Saemundsson (1925) found Long Rough Dabs of up to $42 \mathrm{~cm}$ at Iceland, and the longest recorded by Krüger (1942) for the Baltic was $34 \mathrm{~cm}$. The largest specimen in the 1561 Clyde-caught Long Rough Dabs was $30.5 \mathrm{~cm}$ long.

With the rate of growth, however, no such very great differences are found, particularly in the younger age-groups. The data extracted from the Russian papers are shown in Fig. 4, together with the curves for the Clyde populations. It can be seen that the initial rates of growth are quite comparable, though later differing greatly, and the sexual differences are not apparent in the Russian data. Huntsman does not give any numerical data except as a generalized graph to illustrate that the growth rate varies markedly from place to place, and this is attributed to water-temperature differences. Saemundsson, however, gives sufficient data from Iceland for a comparison to be made between the Clyde and Icelandic populations. This is shown graphically in Fig. 6, which illustrates the data for II-25 June 1924, chosen because it is sufficiently large and quite representative of the other data given.

Krüger's growth rate data from the Baltic (the nearest recorded to the Clyde) is shown in Fig. 6, where it can be seen that the rates are very similar, except for the older females, though the males are almost identical. 


\section{SUMMARY}

The ages of I 426 female, and I 35 male Long Rough Dabs have been determined from otolith readings. The females were found to live into their seventh year and reach $30.5 \mathrm{~cm}$, compared with males that live to their fifth year and reach $19.0 \mathrm{~cm}$ in length. However, the mean increase in length per year for a given length, has been found to be the same. The growth of the females has been shown to fit the equation $l_{t}=26.437\left(\mathrm{I}-0.574^{t}\right)$ and of the males

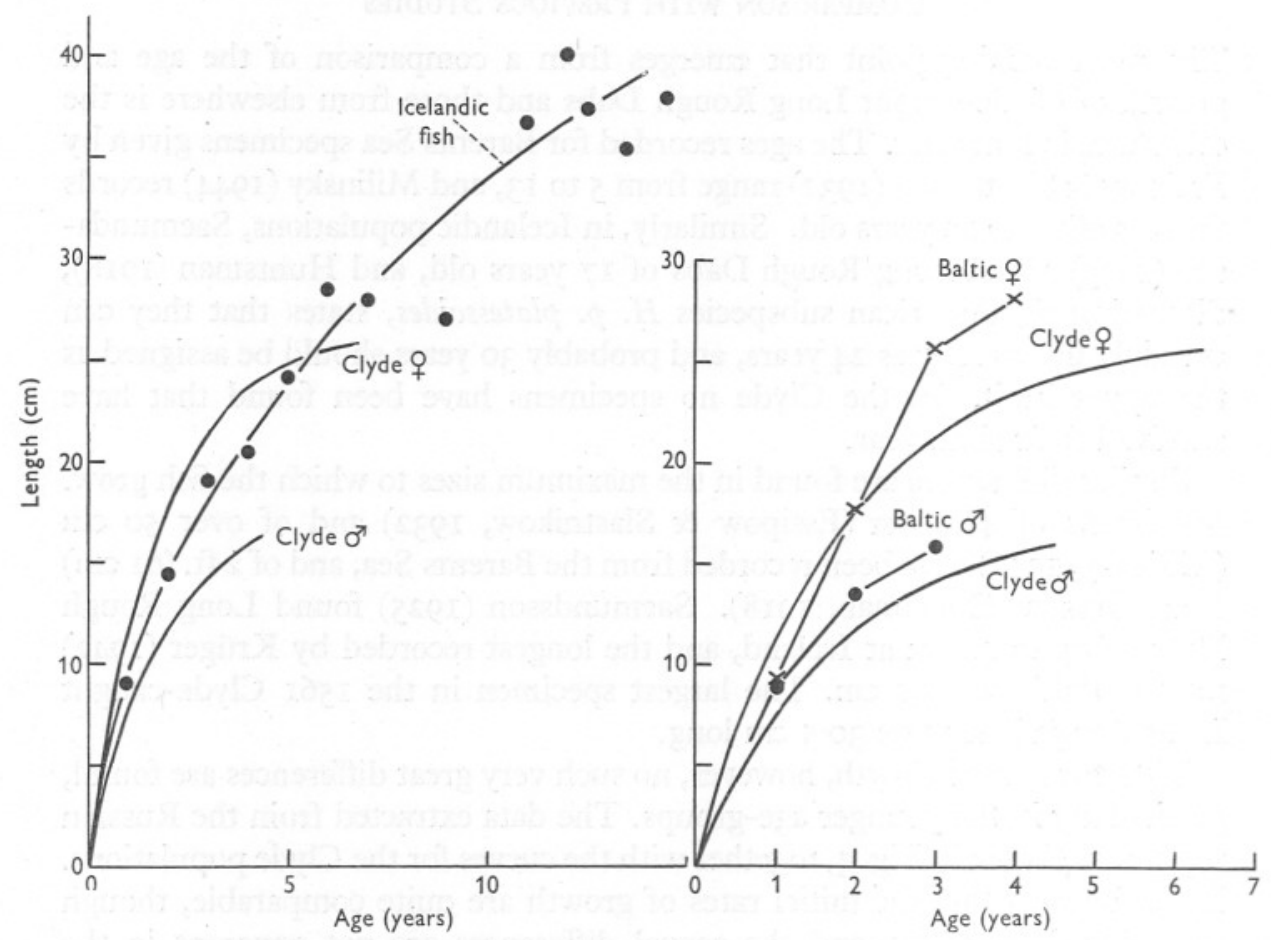

Fig. 5. Growth rate comparison of Clyde and Fig. 6. Growth rate comparison of Clyde and Icelandic Long Rough Dabs. Baltic Long Rough Dabs.

$l_{t}=\mathrm{I} 7 \cdot 754\left(\mathrm{I}-0.585^{t}\right)$. In the case of the females the observed and calculated values agree quite closely, but with the males there is a greater difference, and it is believed that the discrepancy is due to net selection. The suggestion is made that the calculated mean lengths for each age group are better estimates of those of the population than are the observed sample means. The two standard deviations limits can be estimated about the population means and the sample values are found to be within these limits.

Comparison with previous studies shows that the Clyde fish are smaller and shorter-lived than more northern specimens, though broadly speaking the rate of growth for comparable ages is not so dissimilar. 


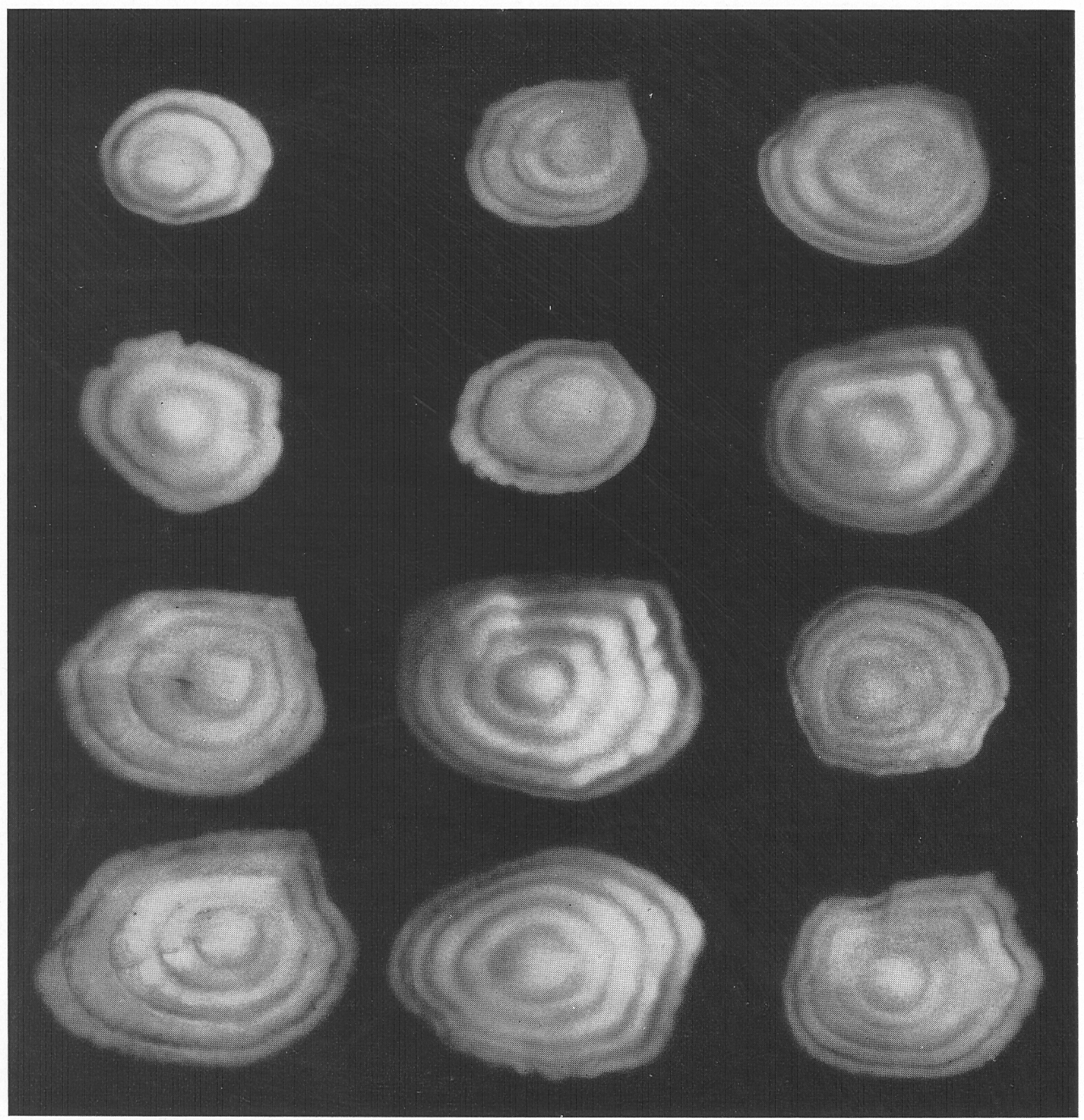

(Facing p. 310) 


\section{REFERENCES}

Bertalanffy, L. von, 1938. A quantitative theory of organic growth. Hum. Biol. Vol. ro, No. 2, pp. I8I-2I3.

- 1949. Problems of organic growth. Nature, Lond., Vol. I63, pp. I56-8.

Essipow, W. J. \& Slastnikow, G., 1932. Zur Biologie des Kambala-jorsch (Drepanopsetta platessoides O. Fabr.) im Barentsmeer. Wiss. Fishereiuntersuchungen am Murman (Barents See). Pp. I9I-8.

ForD, E., I933. An account of the herring investigations conducted at Plymouth during the years from 1924 to I933. F. Mar. biol. Ass. U.K. Vol. I9, pp. 305-84.

Huntsman, A. G., I918. Histories of new food fishes I. The Canadian Plaice. Bull. biol. Bd. Can., No. I, 32 pp.

KRÜGER, K. voN, 1942. Erneutes Auftreten der Scharbzunge, Drepanopsetta platessoides Fabr., in der westlichen Ostsee. Kieler Meeresforsch. Vol. 4.

Milinsky, G. I., I944. On the biology and fisheries of the Long Rough Dab of the Barents Sea. Trans. Knipovich Polyar sci. Inst. Vol. 8, pp. 388-4I5.

Norman, J. R., I934. A Systematic Monograph of the Flatfishes (Heterostomata), Vol. I. London.

Parrish, B. B. \& Jones, R., I953. Haddock bionomics. I. The state of the haddock stocks in the North Sea I946-50 and at Faroe 1914-50. Marine Res. I952, Vol. 4, $27 \mathrm{pp}$.

SAemundSSON, B., I925. Fiskirannsóknir 1923-I924. Andvari, Reykjavik, pp. 33-7I.

WALFORD, L. A., I946. A new graphic method of describing the growth of animals. Biol. Bull., Woods Hole, Vol. 90, pp. I4I-7.

\section{EXPLANATION OF PLATE I}

Otoliths of Long Rough Dabs. Top row : males left to right: 2 rings, $12.5 \mathrm{~cm} ; 3$ rings, $14.0 \mathrm{~cm}$; 4 rings, $19.0 \mathrm{~cm}$. Upper middle row: females, left to right: 2 rings, $17.5 \mathrm{~cm} ; 2$ rings, $16.5 \mathrm{~cm} ; 3$ rings, $22.0 \mathrm{~cm}$. Lower middle row: females, left to right: 3 rings, $22.5 \mathrm{~cm}$; 4 rings, $23.0 \mathrm{~cm} ; 4$ rings, $18.5 \mathrm{~cm}$. Bottom row: females; left to right: 4 rings, $25^{\circ} \mathrm{cm}$; 4 rings, $23.0 \mathrm{~cm} ; 4$ rings, $22.0 \mathrm{~cm}$. 